\title{
The importance of humour and charisma to facilitate students' motivation for learning
}

Andreia Ștefănescu, Petre Daniel Cârciag, Diana Mariana Boeriu, Simona Călina Morar 


\title{
The importance of humour and charisma to facilitate students' motivation for learning
}

\author{
Andreia Ștefănescu ${ }^{\text {a* }}$, Petre Daniel Cârciag ${ }^{b}$, Diana Mariana Boeriu ${ }^{c}$, Simona Călina \\ Morar $^{\mathrm{d}}$
}

\author{
${ }^{a}$ Doctoral School "Educational, Reflection, Development", Babeş-Bolyai University, 7 Sindicatelor Street, 400029, Cluj-Napoca, Romania \\ ${ }^{b}$ Doctoral School, The National University of Physical Education and Sport, 140 Constantin Noica Street, Bucharest, 060057, Romania \\ ${ }^{c}$ Doctoral School "Educational, Reflection, Development", Faculty of Psychology and Educational Sciences, Babeş-Bolyai University, 7 Sindicatelor \\ Street, 400029, Cluj-Napoca, Romania \\ ${ }^{d}$ Doctoral School "Educational, Reflection, Development", Faculty of Psychology and Educational Sciences, Babeş-Bolyai University, 7 Sindicatelor \\ Street, 400029, Cluj-Napoca, Romania \\ *Corresponding author: stefanescu.andreia@gmail.com
}

Abstract

\section{Keywords:}

charisma, games'

functions, learning,

interpersonal relationships, humour

\section{Zusammenfasung}

\section{Schlüsselworte:}

Charisma, Spiele, Funktionen, Lernen, Zwischenmenschliche Beziehungen, Humor
The article presents a synthesis of qualitative studies regarding the importance of using humour and games in learning. Humour has a wide range of functions that make it a valid instrument if used in classroom. It can be used to raise students' motivation and it promotes their psychological and emotional development. This paper presents the results of an enquiry conducted upon a sample of 698 students from the IVth to the VIIIth grade. Among the items we have also included different topics related to the importance of interactive strategies designed to support learning through laughter and to make lessons more attractive. At a theoretical level we will investigate if teacher's charisma is related to the ability to use it in the classroom on one hand and if and how learning is eased. Correlational analysis revealed specific results showing that using humour in education is beneficial to increasing students' motivation.

Der Artikel präsentiert eine Synthese von qualitativen Studien bezüglich der Bedeutung des Einsatzes von Humor und Spielen beim Lernen. Humor hat eine breite Palette von Funktionen, die ihn zu einem validen Instrument machen, wenn er im Klassenzimmer eingesetzt wird. Er kann eingesetzt werden, um die Motivation der Schüler zu erhöhen und er fördert ihre psychologische und emotionale Entwicklung. In diesem Beitrag werden die Ergebnisse einer Untersuchung vorgestellt, die mit einer Stichprobe von 698 Schülern der vierten bis achten Klasse durchgeführt wurde. Unter den Items haben wir auch verschiedene Themen aufgenommen, die sich auf die Bedeutung von interaktiven Strategien beziehen, die das Lernen durch Lachen unterstützen und den Unterricht attraktiver machen sollen. Auf theoretischer Ebene untersuchen wir, ob das Charisma des Lehrers einerseits mit der Fähigkeit zusammenhängt, es im Klassenzimmer einzusetzen, und ob und wie das Lernen erleichtert wird. Die Korrelationsanalyse ergab konkrete Ergebnisse, die zeigen, dass der Einsatz von Humor im Unterricht zur Steigerung der Motivation der Schüler beiträgt.

\section{Introduction}

Since ancient times humour has proved to have an important role in enhancing relations between people, adjusting behaviors and education. Within the learning process, humour can be used both as a strategy and an instrument to enhance and enrich the content and learning methods.

According to the Oxford Dictionary the word ludic is defined as ,tending to play and have fun, make jokes, etc., especially when there is no particular reason for doing this". Ludic covers everything that facilitates building knowledge in a free and spontaneous manner. It enhances activities with joy satisfaction and enthusiasm while giving access to knowledge and better understanding the world. If implicated in ludic activities children's imagination and creativity is improved while informal learning is increased as children aren't focused upon language but upon games and fun. Knowledge gets real (Constantinides, 2009).

If we take a look at the most important aspects we notice that ludic and humour are similar in terms of fun and amusement. Humour though uses more language and less games. Therefore this paper uses both terms as they can be switched according to the objectives.

Activities implying ludic and humour elements have significant effects in motivating students. Motivation is a primary learning mechanism and lately it works as a continuous force sustaining cognitive efforts needed in learning and operations with the new knowledge regardless the subject (Enever, 2015). 
Teacher can be perceived as a leader within the classroom as he is coordinating a group or activity.

Charisma represents a tool to influence other's behaviors and to earn the loyalty of the group. (Macarie, 2007, quoted by Karim, Mansir andSaparudin, 2020). Charismatic leaders can imbue students with motivation, share their prospective and provide openness to the ideas and the needs of the members. (Kelinman, 2004, quoted by Karim, Mansir andSaparudin, 2020).

Humours phychosocial's component can be also found within al socio-cultural groups. Besides the roles related to belonging to a group and inclusion, humour has an instructive function. That is the reason why introducing humour in classroom and discovering its effect has become a research topic.

\section{Theoretical frame and literature review}

The scientific literature has demonstrated through a large number of studies that there is a tangible connexion between expressing ludic through humour and reducing conflicts, and improving the quality of relationships. (Berger, 1956; Gorham andChristophel, 1990; Sidelinger, 2014).

The teacher-student interactions are getting improved by ludic elements. Smith, Ascough, Ettinger andNelson (1971) have conducted a study on a number of 215 students. They were asked was to solve an academic task. Students were divided into two groups. One group had to perform a task containing funny elements in a proportion of $30 \%$, and the other had to perform a task with no funny elements in it. The results have shown that exposing students to fun decreased their anxiety level and increased their academic performance.

Kane, Suls andTedeschi (1977) determined that in the classroom there are many psychosocial functions of humour that are activated, such as: reducing pressure, improving the negative emotions' level in difficult situations, facilitating the process of getting to know each other or simply the entertainment.

It's been proved that humour has a positive impact on interpersonal relationships and on the group cohesion (by group we mean the class group)(Sprowl, 1987). Teachers who bond with their students are more likely to use humour in teaching (Gorham, 1988). In the same time people using humour are characterised as being more nice and attractive compared to people who don't.

In a positive situation people are more available to relating with others (Gorham andChristophel, 1990). Deiter (2000) explains that using humour in the classroom becomes a tool teacher use to maximize students' results and there's no negative impact on teacher's reputation or authority.

Humour is also a way to reduce emotional barriers that occur in communication. Moreover humour has an important contribution to a conducive learning environment. Therefore it becomes a pedagogical instrument that allows the merger between formal linguistic features and social-cultural features of the group (Askildson, 2005).

Lovorn (2008) emphasizes the importance of using humour in preadolescence both by teachers and parents. The explanation consists in the fact that exposing regularly the pre-teens to humour leads to social and intellectual development if humour is structured and correct.

An additional argument is offered by Morrison (2012) who identifies ten reasons why he encourages the using of humour in the classroom:

a) All discussions containing humour led by a teacher are better remembered by students on long-term;

b) Humour helps creating coping mechanisms while helping children relax in difficult situations or with difficult tasks;

c) Humour leads to positive reactions such as stimulating interactions and commitment;

d) Humour helps students focus better and for a longer period of time;

e) Humour wipes fatigue and stress both for students and teachers;

f) Humour doesn't help students to learn the entire content but eases the learning of the message and context

g) Humour stimulates creativity;

h) Humour facilitates communication and interactions;

i) Humour is useful in the process of change;

j) Humour is... free and fun.

Using humour has benefits for all ages, starting with pre-schoolers and finishing with college students. The most frequent types of humour are the jokes, fun images, stories and pictures and all those can be successfully used both in school and on-line for all subjects (Ivy, 2013).

However there are also negative aspects of using humour in teaching as some studies are showing. Furthermore we present a few limits of using humour in schools: ridicule students who break the rules, emphasizing features that make students different (discriminating students). All the above are leading to negative reactions and conflicts between or inside a group (Cann, Zapata and Davis, 2009).

One of the main conditions when using the ludic resource in classroom is to create a context or situation that is conducive to this. This is a resource teachers have to be fully aware when they choose to use it and it has to be related to teacher's objective. The most frequent objectives are related to: making a change in a student's behavior, getting students focused, the transition from one topic or task to another (Shibinski and Martin, 2010).

Humour has two components: the cognitive one and the emotional one. If students cannot understand their teacher's humour they won't be able to process the message. From this point of view it is compulsory that humour is accessible to student's age range and knowledge (Banas, Dunbar, Rodriguez and Liu, 2011). 
Hellman (2007) presents a set of rules teachers have to follow when they choose to use humour in the classroom:

- they have to carefully choose the time

- the professional climate must not be affected by the using of humour;

- even if the teacher choose to explain some concepts using humour he then has to review the content in a scientific manner;

Students appreciate teacher's qualities when they manage to create a psycho-social climate that is conductive to modern learning (where examples and funny stories are used, combined with information from the media). All these strategies will direct students' focus or change negative angles towards information or events. The satisfaction will therefore be maintained (Sidelinger, 2014).

Grant (2015) uses the term "good teacher" to depict this particular type of a teacher: his lectures are attractive to students, he is charismatic and a good practitioner and also thinks about the teaching process. Teacher's behavior influences the learning process of his students.

Lin and Huang (2016) explain in their study that students' interests for learning are increased when their teachers are charismatic and decreases is teachers are not. The conclusions of the study are that one of the indicators that predicts the students' success is teachers' charisma.

Charismatic teachers are admired by other people as they have a pleasant and genuine appearance, by presenting contents in an original manner and the persuasive speech (Juvan, 2017).Dobrovská (2018) made a list of components of the charismatic teacher's activity:

a) The teacher is an expert in his field while the content is processed and adapted to the particularities of the group;

b) When framing the topic he includes original approaches as a consequence of a profound reflection;

c) $\mathrm{He}$ is self-taught and focused upon examples and explanations that are accessible to students and their needs. This always happens as this teacher is open to new ideas and modern resources;

d) He is an authentic person presenting an authentic and significant information;

e) The presentations are coherent and can combine both contents and details;

f) $\mathrm{He}$ is assertive and gives confidence to students;

g) $\mathrm{He}$ is positive, dynamic and stimulates students to be implicate in different activities;

h) The charismatic teacher has acting skills to keep students focused;

i) He uses non-verbal language and voice tone in teaching to enhance the content;

j) He has a good image on himself and gives his students confidence;

k) He is fully aware on the importance of the subject and the context of the subject he teaches;

1) He leads students to cognitive and spiritual development.
Charisma is seen as a vector of performance and innovation in educational systems. But innovation is only possible if the managers are open-minded when it comes to change and teachers are available to the new ideas (Ismail and Mydin 2019).

\section{Research design}

\subsection{Aim and objectives}

The research represents a selection of some particular items concerning interactive teaching and using humour selected from a research which included different topics.

The starting point of this research was the following question: To what extent the teaching strategies using humour as a teaching instrument are perceived by the students of different age range as playing a positive role in learning?

The aim of the research is to assess the role of interactivity in teaching-learning process as wellas the role of humour in:increasing learning motivation and perception of learning difficulty.

In order to achieve this goal, we evaluated the results obtained after applying a questionnaire that included several items corresponding to the proposed objectives.

The objectives of the research are:

O1. To assess to what extent interactivity correlates with the perception of students upon the learning process;

O2. To assess to what extent interactivity correlates with the perception of students upon the education' goal;

O3. To assess to what extent interactivity correlates with the perception of students upon the importance of humour/laughter in classroom.

3.2. Methodology: the instrument and the procedure

In this research we used a questionnaire that includes two dichotomized Likert scales. The scale has a number of 10 items and investigated students' opinions about:

- The interactivity of teaching

- The difficulty of learning

- Their perception upon learning objectives

- Their confidence in teachers.

\subsection{The sample}

698 students answered the questionnaires according to tables and diagrams below:

Descriptive statistics of the sample

By gender: 309 (44.3\%) of students were boys and389 $(55.7 \%)$ were girls. The number of boys and girls and percentages are shown below:

Table 1. Sample distribution by gender

\begin{tabular}{|c|c|c|}
\hline Gender & Number & Percentage \\
\hline Boys & 309 & $44.3 \%$ \\
\hline Girls & 389 & $55.7 \%$ \\
\hline Total & 698 & $100 \%$ \\
\hline
\end{tabular}

Students' distribution according to their grade: the distribution was relatively homogenous (there were slightly 
more students in the $\mathrm{IX}^{\text {th }}-\mathrm{X}^{\mathrm{th}}-\mathrm{XI}^{\mathrm{th}}$ grade as shown in the table below:

Table 2. Sample distribution bygrade

\begin{tabular}{|l|r|r|}
\hline \multicolumn{1}{|c|}{ Grade } & Number & Percentage \\
\hline IV $^{\text {th }}$ & 67 & $9.6 \%$ \\
\hline $\mathrm{V}^{\text {th }}$ & 54 & $7.7 \%$ \\
\hline VI $^{\text {th }}$ & 45 & $6.4 \%$ \\
\hline VII $^{\text {th }}$ & 49 & $7.0 \%$ \\
\hline VIII $^{\text {th }}$ & 55 & $7.9 \%$ \\
\hline IX $^{\text {th }}$ & 125 & $17.9 \%$ \\
\hline X $^{\text {th }}$ & 115 & $16.5 \%$ \\
\hline XI $^{\text {th }}$ & 115 & $16.5 \%$ \\
\hline XII $^{\text {th }}$ & 73 & $10.5 \%$ \\
\hline Total & 698 & $100 \%$ \\
\hline
\end{tabular}

We have also considered important to the accuracy of the aims of the research to include both students from urban and rural environment. Sample distribution by urban - rural area of residence is shown in the table below:

Table 3. Sample distribution by residence area (urban rural)

\begin{tabular}{|l|c|c|}
\hline Residence area & Number & Percentage \\
\hline Urban & 485 & $70 \%$ \\
\hline Rural & 213 & $30 \%$ \\
\hline Total & 698 & $100 \%$ \\
\hline
\end{tabular}

\section{Results. Data analysis}

Under the data analysis, exploration of data has been made with descriptive statistics and graphical analysis. The students' answers to every item or group of items were independently analysed.

4.1. Analysing the extent to what students prefer charismatic teachers (teachers that are using humour and are flexible)

Considering all data presented above we can assert that students think that: learning is difficult as they are not involved in interactive activities comprising humour; humour would make lessons more attractive and also would support learning; therefore the learning process is dull and meaningless to students when teachers are severe and they lack charisma and humour.
Data analysis was exhaustive. From this analysis we concluded that only for 215 students (less than $30.8 \%$ ), serious teachers (those whose interests are mostly related to teaching and less to bonding with students) are the ones they prefer.

A number of 483 students $(69.2 \%)$ prefer charismatic teachers as they are perceived as facilitators, as teachers that bond with students and make teaching-learning activities meaningful. Therefore, this is the type of teacher most students prefer. The distribution of these perceptions is represented in the table below:

Table 4. The extent to what students prefer charismatic teachers

Item - The preferences for serious and charismatic teachers

\begin{tabular}{|l|l|r|r|}
\hline Answers & Serious teachers & 215 & $30.8 \%$ \\
\cline { 2 - 4 } & $\begin{array}{l}\text { Charismatic } \\
\text { teachers }\end{array}$ & 483 & $69.2 \%$ \\
\cline { 2 - 4 } & Total & 698 & $100 \%$ \\
\hline
\end{tabular}

4.2. The extent to what students prefer fun but meaningful activities

Our aim was to study how much learning facilitators can provide active learning, interactive and dynamic activities. In order to do that we studied their answers to the questions about boredom and meaningful laughter during lessons.

Data analysis revealed that most of students perceive lessons are not dynamic nor active and interactive. $63 \%$ of the students think lessons are boring and not challenging. It is very possible that for this reason lessons are seen as difficult (by 58\% of the students) when there isn't meaningful humour (see Table 5):

Table 5. The perception on learning

\begin{tabular}{|l|l|}
\hline Items & Percentage \\
\hline $\begin{array}{l}\text { Teaching-learning activities are } \\
\text { boring and less challenging when } \\
\text { there is no meaningful humour }\end{array}$ & $63 \%$ \\
\hline $\begin{array}{l}\text { Learning is considered more difficult } \\
\text { when there is no meaningful humour } \\
\text { during the lessons }\end{array}$ & $58 \%$ \\
\hline
\end{tabular}

As the number of students who scored for the two variables as shown in the table above (the lack of interactive activities and the difficulty of learning) we decided to explore from a statistical point of view if there is an interrelation between the variables and humour. Therefore we calculated the Pearson correlation coefficient. The data collected through this method is shown below: 
Table 6. Pearson correlations between responses to "interactive activities","the difficulty of learning"and "humour and meaningful laughter during lessons"

\begin{tabular}{|c|c|c|c|c|}
\hline \multicolumn{2}{|l|}{ Variables } & $\begin{array}{c}\text { Perceived interactive } \\
\text { activities }\end{array}$ & $\begin{array}{l}\text { Perceived } \\
\text { difficulty of } \\
\text { learning }\end{array}$ & $\begin{array}{l}\text { Perceived humour and } \\
\text { meaningful laughter } \\
\text { during lessons }\end{array}$ \\
\hline \multirow[t]{3}{*}{$\begin{array}{l}\text { Perceived interactive } \\
\text { activities }\end{array}$} & $\begin{array}{l}\text { Pearson } \\
\text { Correlation }\end{array}$ & 1 & $-0.822^{* * *}$ & $0.765^{* *}$ \\
\hline & Sig. (2-tailed) & & .000 & .000 \\
\hline & $\mathrm{N}$ & 698 & 698 & 698 \\
\hline \multirow[t]{3}{*}{$\begin{array}{l}\text { Perceived difficulty } \\
\text { of learning }\end{array}$} & $\begin{array}{l}\text { Pearson } \\
\text { Correlation }\end{array}$ & $-0.822^{* *}$ & 1 & $0.125^{* *}$ \\
\hline & Sig. (2-tailed) & .000 & & .000 \\
\hline & $\mathrm{N}$ & 698 & 698 & 698 \\
\hline \multirow{3}{*}{$\begin{array}{l}\text { Perceived humour } \\
\text { and meaningful } \\
\text { laughter during } \\
\text { lessons }\end{array}$} & $\begin{array}{l}\text { Pearson } \\
\text { Correlation }\end{array}$ & $0.765^{* *}$ & $0.125^{* * * *}$ & 1 \\
\hline & Sig. (2-tailed) & .000 & .000 & \\
\hline & $\mathrm{N}$ & 698 & 698 & 698 \\
\hline
\end{tabular}

Table 6 shows that all three variables are interdependent with both positive and negative values $(p<$ $0.001)$. The Pearson correlations for the variables introduced in the analysis are statistically significant. All data presented in the table above led us to the following conclusions:

- Interactivity in learning perception is negatively correlating with students' perception upon the difficulty of learning $(\mathrm{r}=-0.82$ - statistically significant). The more interactive lessons are the fewer students perceive learning as being difficult.

- Interactivity in learning perception is positively correlating with students' perception upon the aim of learning $(\mathrm{r}=0.76$ - statistically significant $)$. If lessons are interactive there is much more humour and laughter in the classroom.

- The extent to what students perceive the difficulty of learning is not correlated to their perception upon the importance of humour and laughter during lessons $(r=0.12$ - statistically significant). We can conclude that during difficult lessons, charismatic teachers who also use humour will reduce the difficulty level of learning. Humour can be used in lessons regardless the difficulty level.

\section{Conclusions}

The answer to the primary question is that there is a large extent up to which lessons involving humour is perceived by the students as having a positive role in the learning process regardless the grade (we included students from the IV $^{\text {th }}$ to XII ${ }^{\text {th }}$ grade).

The aims of the research were met and the results are indicating that:

i) Interactivity in learning is negatively correlating with students' perception upon the difficulty of learning $(r=$ -
0.82). The more interactive lessons are the fewer students perceive learning as being difficult.

ii) Interactivity in learning is positively correlating with students' perception upon the aim of learning $(\mathrm{r}=0.76)$. If lessons are interactive there is mисh more humour and laughter in the classroom.

iii)The extent to what students perceive the difficulty of learning is not correlated to their perception upon the importance of humour and laughter during lessons ( $\mathrm{r}=$ 0.12 ).

The main conclusions from the results are:

a) The more interactive are the lessons (perceived), the less difficult the students perceive learning.

b) The more interactive are the lessons (perceived), the more increased the quality of humour and laughter is (declared).

c) When it comes about difficult lessons, charismatic teachers using humour will contribute to the diminishing of the perceived difficulty of learning.

A general conclusion of this research after the analyze of the results is that integrating humour elements in teaching (using specific techniques and instruments correlated to the subjects) could be a useful way to capitalize those elements supporting learning. Humor becomes a natural extension to social interactions within the group. This way, academic acquisitions are more likely to be considered from a formative perspective. Also, academic acquisitions will meet the specific competences as well as transversal competences.

\section{Authors note:}

Andreia Ștefănescu is currently the President of the Romanian Association for Research and Innovation which provides professional training coursesfor teachers 
accredited by the Ministry of Education and Research. Mrs. Andreia Ștefănescu is also a PhD student at Babeș-Bolyai University Cluj-Napoca. She is currently studying the phenomenon of cohesion within schools groups.

Petre Daniel Cârciag is $\mathrm{PhD}$ student at the Doctoral School of the Faculty of Physical Education and Sports at the University of Bucharest, Headteacher of Inclusive Education Center Băbeni.

Diana Mariana Boeriu is a preschool teacher and $\mathrm{PhD}$ student at Babeș-Bolyai University Cluj-Napoca. Her field of interest include the implication of modern games and toys use in socio-emotional development of preschool pupils.

Simona Călina Morar is a preschool teacher, methodist at the Cluj County School Inspectorate and PhD student at Babeș-Bolyai University Cluj-Napoca. Her field of interest includes formal and non-formal educational activities.

\section{References}

Askildson, L. (2005). Effects of humor in the language classroom: Humor as a pedagogical tool in theory and practice. Journal of Second Language Acquisition and Teaching, 12, 45-61.

Banas, J.A., Dunbar, N., Rodriguez, D., \& Liu, S. J. (2011). A review of humor in educational settings: Four decades of research. Communication Education, 60(1), $115-144$.

Cann, A., Zapata, C.L., \& Davis, H.B. (2009). Positive and negative styles of humor in communication: Evidence for the importance of considering both styles. Communication Quarterly, 57(4), 452-468.

Constantinides, M. (2009). The power of play for education and language development. accessed at: http://marisaconstantinides.edublogs.org/2009/09/02/t he-power-of-playfor-education-and-languagedevelopment/\#.WBN4GQrK-U

Deiter, R. (2000). The use of humor as a teaching tool in the college classroom. NACTA Journal, 20-28.

Dobrovská, D. (2018). One More Way How to Improve the Higher Education Teaching. An independent scientific journal for interdisciplinary research in pedagogy, 7.

Enever, J. (2015). The advantages and disadvantages of English as a foreign language with young learners. In J. Bland (Ed), Teaching English to Young Learners. Critical Issues in Language Teaching With 3-12 Year Olds (pp.13-27). London: Bloomsbury.

Grant, K.A. (2015). From lists to images: Exploring the concept of the good teacher in teacher education. Journal of the Canadian Association for Curriculum Studies, 13(1), 36-59.

Gorham, J. (1988). The relationship between verbal teacher immediacy behaviors and student learning. Communication education, 37(1), 40-53.

Gorham, J. \&Christophel, D.M. (1990). The relationship of teachers' use of humor in the classroom to immediacy and student learning. Communication education, 39(1), 46-62.

Hellman, S.V. (2007). Humor in the classroom: Stu's seven simple steps to success. College Teaching, 55(1), 3739.

Ismail, A.\&Mydin, A.A. (2019, March). The impact of transformational leadership and commitment on teachers' innovative behaviour. In 4th ASEAN Conference on Psychology, Counselling, and Humanities (ACPCH 2018). Atlantis Press.

Ivy, L.L. (2013). Using humor in the classroom. The Education Digest, 79(2), 54

Juvan, M. (2017). The charisma of theory. In Policing literary theory (pp. 89-110). Boston: Brill Rodopi.

Kane, T.R., Suls, J., \& Tedeschi, J.T. (1977). Humour as a tool of social interaction. In It's a funny thing, humour (pp. 13-16). Qxford: Pergamon.

Karim, A., Mansir, F., \&Saparudin, T. (2020). Managerial Leadership in Boarding and Public School: An Idea and Experience from Indonesia. Journal of Talent Development and Excellence, 12(2s), 4047-4059.

Lin, S.H.\& Huang, Y.C. (2016). Examining charisma in relation to students' interest in learning. Active Learning in Higher Education, 17(2), 139-151.

Lovorn, M.G. (2008). Humor in the home and in the classroom: The benefits of laughing while we learn. Journal of Education and Human Development, 2(1).

Morrison, M.K., \& Quest, H. (2012). The top ten reasons why humor is FUNdamental to education. Creating an Appropriate 21 st Century Education, 48.

Shibinski, K. \& Martin, M. (2010). The role of humor in enhancing the classroom climate. International Journal of Athletic Therapy and Training, 15(5), $27-$ 29.

Sidelinger, R.J. (2014). Using relevant humor to moderate inappropriate conversations: Maintaining student communication satisfaction in the classroom. Communication Research Reports, 31(3), 292-301.

Smith, R.E., Ascough, J.C., Ettinger, R.F., \& Nelson, D.A. (1971). Humor, anxiety, and task performance. Journal of Personality and Social Psychology, 19(2), 243.

Sprowl, J. (1987). Humor theory and communication research. World Communication, 16(1), 47-65.

*** (2019). 'Ludic'. Oxford Dictionary. accessed at: https://www.oxfordlearnersdictionaries.com/ 